\title{
In vitro and in vivo biological control of the green mold using different bacteria in button mushroom cultivation
}

\author{
Mehmet Aydoğdu*, Serap Melike Sülü, Illker Kurbetli and Görkem Sülü
}

\begin{abstract}
Background: Aggressive biotype (Trichoderma aggressivum f. aggressivum) of green mold is one of the main biotic factors limiting button mushroom (Agaricus bisporus) cultivation. Due to issues such as fungicide resistance, cost, and adverse effects, biological control seems to be an applicable management method against the green mold in button mushroom cultivation.

Results: The objective of the study was to assess biological control of green mold in button mushroom cultivation. Five native bacterial isolates from mushroom compost and 3 commercial biological preparations were tested against two isolates of $T$. aggressivum f. aggressivum. Dual culture tests were used in vitro experiments. In vivo, compost and casing soil experiments were conducted by comparing yield values of treated plots with negative and positive controls. In vitro, the bacterial isolates inhibited mycelial growth of isolates of $T$. aggressivum $\mathrm{f}$. aggressivum and A. bisporus up to 46.60 and 56.94\%, respectively. In vivo, in the compost experiment, compared with positive control plots, bacterial isolate MSG-5 (Bacillus subtilis) caused the highest yield increase (40.56\%) in the treatments. In the casing soil experiment, commercial biological preparation Tic-3 (Ampelomyces quisqualis) caused the highest yield increase (36.15\%) in the treated plots. Compared with positive and negative controls, all the treatments caused $30.23 \%$ increase but $4.86 \%$ decrease in yield of A. bisporus in the compost experiment, respectively. However, they caused $20.25 \%$ increase but $17.33 \%$ decrease in the yield of A. bisporus in the casing soil experiment, respectively.
\end{abstract}

Conclusions: Results suggested that biological control of the green mold in compost can be more efficient than casing soil in button mushroom cultivation.

Keywords: Bacteria, Biological control, Green mold, Button mushroom

\section{Background}

Button mushroom (Agaricus bisporus) is the most cultivated mushroom in the world. One of the main constraints to button mushroom cultivation is the green mold disease. Trichoderma aggressivum f. aggressivum and T. aggressivum f. europaeum, aggressive biotypes of green mold, cause epidemics and yield losses by $100 \%$ in North America and Europe, respectively (Hatvani et al. 2007). T. aggressivum f. aggressivum was known to occur

\footnotetext{
* Correspondence: mehmet9498@yahoo.com

Department of Plant Health, Batı Akdeniz Agricultural Research Institute, 07100 Antalya, Turkey
}

\section{Springer Open}

in North America, but it was also reported in Hungary and Turkey (Aydoğdu et al. 2020), indicating that apart from North America, this aggressive biotype of green mold is spreading and posing a new risk to other button mushroom-growing countries.

Despite the destructive yield losses and epidemics caused by the aggressive biotypes of green mold, little is known about their management in button mushroom cultivation. Moreover, in the management of pathogens of button mushroom, few chemicals are registered due to sensitivity of mycelium of $A$. bisporus to various molecules including chemicals (Šantrić et al. 2018). In

(c) The Author(s). 2021 Open Access This article is licensed under a Creative Commons Attribution 4.0 International License, which permits use, sharing, adaptation, distribution and reproduction in any medium or format, as long as you give appropriate credit to the original author(s) and the source, provide a link to the Creative Commons licence, and indicate if changes were made. The images or other third party material in this article are included in the article's Creative Commons licence, unless indicated otherwise in a credit line to the material. If material is not included in the article's Creative Commons licence and your intended use is not permitted by statutory regulation or exceeds the permitted use, you will need to obtain permission directly from the copyright holder. To view a copy of this licence, visit http://creativecommons.org/licenses/by/4.0/. 
addition, there is a high risk of residues of pesticide on button mushrooms picked for marketing. Since button mushrooms emerge and then reach adequate size for picking within a short period of time after application of chemicals to casing soil. Pesticide resistance and their cost are also additional problems in button mushroom cultivation. For these reasons, the button mushroom sector is under pressure in terms of human and environmental health and food safety (Savoie et al. 2016). Therefore, alternative management strategies should be developed in the management of green mold in button mushroom cultivation. With regard to alternative management practices, several in vitro studies were performed using essential oils (Đurović-Pejčev et al. 2014). However, cost and application difficulties in vivo and adverse effects of essential oils on the mycelium of $A$. bisporus are issues that must be handled (Geösel et al. 2014). In this regard, biological control comes to the forefront with its certain features such as being specific to target microorganism, cost-effective, and environmentally friendly (Stanojević et al. 2016).

There are a few examples of biological control in the management of the green mold in button mushroom cultivation (Milijašević-Marčić et al. 2017). However, findings of experiments in vitro may not reflect in vivo (Stanojević et al. 2016) because button muhrooms are cultivated in microorganism-rich media like compost and casing soil. In such media, a vast number of fungi and bacteria are involved in complex interactions varying from mutualism to antagonism. These interactions might affect any growth stage of $A$. bisporus and consequently mushroom yield depending on the presence of microorganisms in the same medium (Deveau et al. 2018 and Carrasco and Preston 2020). In addition, one of the major interference in the aforementioned complex interactions might occur in the presence of green mold in compost and casing soil (Aydoğdu et al. 2020). In this context, a plausible biological control strategy should be created based on two assumptions; formation of biological control methods against green mold in compost and casing soil. Thus, the aims of this study were (i) to examine effects of 5 native bacterial isolates on mycelial growth of the two isolates of T. aggressivum $\mathrm{f}$. aggressivum and one strain of $A$. bisporus in vitro and (ii) to assess biocontrol efficacy of the bacterial isolates and 3 commercial biological preparations against the two isolates of T. aggressivum f. aggressivum in compost and casing soil.

\section{Methods}

Agaricus bisporus (button mushroom) strain, mushroom compost, and casing soil

Commercial white (192915 AG, Soc, France) strain of $A$. bisporus, mushroom compost and casing soil were obtained from SMS Ersanlar company in Korkuteli county, Antalya province, Turkey. Trademarks of compost and casing soil were Ersan and Çivril, respectively. Composition of the casing soil consisted of organic matter, silt, and various elements (e.g. C, N, P, K, Ca, Mg). No treatment was applied to the casing soil.

\section{Green mold isolates}

Two isolates, Çom1 (Accession number: MH133213 in Genbank (http://www.ncbi.nlm.nih.gov)) and K39 (Accession number: MH133214) of T. aggressivum f. aggressivum, were used from culture collection of the mycology laboratory of Batı Akdeniz Agricultural Research Institute. Both isolates, Çom1 and K39, were previously isolated from mushroom compost in Çomaklı village and Akyar district of Antalya province, respectively in 2015 (Aydoğdu et al. 2020). The isolates were grown on potato dextrose agar (PDA) at $25{ }^{\circ} \mathrm{C}$ for 10 days. Under these conditions, they initially formed whitish colonies, and 4 to 5 days later, colonies began to turn green as a result of sporulation.

\section{Bacterial isolates}

In 2019, five bacteria were isolated from mushroom compost (Phase 3). Samples were obtained from mushroom farms in the Korkuteli county, Antalya province. These bacterial isolates were designated as MSG-5, MSG-11, MSG-15, SGM-1, and SGM-2.

\section{Identification of the bacterial isolates}

Morphological and biochemical traits of each bacterial isolate were examined in vitro. Gram reactions of the bacterial isolates were determined by mixing bacteria with a drop in 3\% solution of $\mathrm{KOH}$ (Suslow et al. 1982). Biochemical traits of the bacterial isolates were characterized according to the standard methods of Bergey's Manual of Determinative Bacteriology (Holt et al. 1994).

To confirm morphological and biochemical identification, molecular diagnosis was also performed. DNA of each bacterium was extracted and purified, using Promega DNA purification kit. 16S rRNA was amplified, using universal oligonucleotide primers, 27F (5'-AGA GTT TGA TCC TGG CTC AG-3') and 1492R (5'-GGT TAC CTT GTT ACG ACT T-3') (Lane 1991; Kadaikunnan et al. 2015). In addition, gyrA gene was amplified, using primers 5'-CAG TCA GGA AAT GCG TACGTC CTT-3' (forward primer) and $5^{\prime}$-CAA GGT AAT GCT CCA GGC ATT GCT-3' (reverse primer) (Chun and Bae 2000).

PCR products were seperated from $1.5 \%$ agarose gels, stained with safe DNA dye and visualized under UV light. Sequence analysis was done by Letgen (Kazım Dirik Mah. 296/2 Sok. No:33 35100 Bornova/İzmirTurkey). The sequences were compared to BLAST 
searches (http://www.ncbi.nlm.nih.gov) to find the closest sequence matches and deposited at the GenBank.

\section{In vitro experiments}

Dual culture tests were used to examine effects of the bacterial isolates on mycelial growth of T. aggressivum $\mathrm{f}$. aggressivum and $A$. bisporus. Owing to weak mycelial growth of $A$. bisporus on artificial media (e.g., potato dextrose agar and so on), compost extract medium (CEM) was prepared as described by Rainey (1989) and used to secure mycelial growth of $A$. bisporus in vitro experiments.

\section{Effects of bacterial isolates on T. aggressivum $f$. aggressivum and $A$. bisporus}

One mycelial plug $(0.5 \mathrm{~cm})$ of each isolate of $T$. aggressivum $\mathrm{f}$. aggressivum was placed at nearly $2-\mathrm{cm}$ away from the edge of a Petri dish ( $9 \mathrm{~cm}$ in diameter) containing CEM and a loopful of each bacterial isolate was streaked to the opposite side. The same process was performed for each interaction and incubated at $25{ }^{\circ} \mathrm{C}$ for 7 days. The experiments were set up according to the completely randomized factorial design with four replications. In the controls, only mycelial plugs of the isolates of $T$. aggressivum $\mathrm{f}$. aggressivum were placed. In each treatment, colony radial growth of $T$. aggressivum $\mathrm{f}$. aggressivum was measured, using a caliper and compared with the control. Five days later, growth inhibition of $T$. aggressivum f. aggressivum caused by each bacterial isolate was determined, using the formula below (Vinale et al. 2008).

Growth inhibition ratio $(\%)=(\mathrm{R} 1-\mathrm{R} 2 \div \mathrm{R} 1) \times 100$,

where $\mathrm{R} 1$ = colony radial growth $(\mathrm{mm})$ of $T$. aggressivum f. aggressivum in the control and R2 = colony radial growth $(\mathrm{mm})$ of $T$. aggressivum $\mathrm{f}$. aggressivum in the treatment.

Three spawn grains covered by white strain (192915 AG, Soc, France) of $A$. bisporus were placed on CEM and incubated at $25^{\circ} \mathrm{C}$ for 7 days. To use in dual culture tests, mycelial plugs $(0.5 \mathrm{~cm})$ of the strain of $A$. bisporus were taken from the 7-day-old colonies growing on CEM, and as aforementioned, dual culture tests were conducted with the bacterial isolates. The experiments were set up according to the completely randomized design with 4 replications. In the controls, only mycelial plugs of the strain of $A$. bisporus were placed on CEM. In each treatment, colony radial growth of the strain of $A$. bisporus was measured, using a caliper and compared with the control. Fourteen days later, growth inhibition of $A$. bisporus caused by each bacterial isolate was determined, using the above formula of Vinale et al. (2008).

\section{In vivo experiments}

\section{Commercial biological preparations}

In addition to the native bacterial isolates, 2 commercial bacterial preparations and one fungal biological preparation were also used in vivo experiments. These commercial preparates were designated as Tic-1, Tic-2, and Tic-3, and their commercial names were Serenade (SC), Cedriks (SL), and Ovnier (SL), respectively.

\section{Preparation of bacterial suspensions of the native isolates}

Bacterial suspension of each isolate was prepared from 2-day-old cultures grown on nutrient agar medium. Inoculum concentration was adjusted to $10^{8} \mathrm{cfu} / \mathrm{ml}$, using sterile distilled water in a spectrophotometer (SHIMADZU UV-120-01).

\section{Preparation of green mold inoculum}

Each isolate of $T$. aggressivum f. aggressivum was incubated on PDA at $25{ }^{\circ} \mathrm{C}$ for 10 days. Later, $12 \mathrm{ml}$ sterile distilled water per Petri dish was added to the colony of each isolate growing on PDA. Spore suspension was sieved through a muslin and transferred to a 2-1 beaker. Spore density was adjusted to $1 \times 10^{6}$ conidia/ml, using a hemocytometer.

\section{Preparation of casing soil}

Commercial casing soil was passed through a sieve to remove big pieces from it.

\section{Providing mushroom-growing conditions}

Mushroom-growing conditions (temperature, humidification, and ventilation arrangements) were provided in a room in the basement of the Department of Plant Health of Batı Akdeniz Agricultural Research Institute, Antalya province. For assessments of biological control of green mold in compost and in casing soil, 2 separate experiments were conducted.

\section{Compost and casing soil experiments}

Compost experiment was carried out according to a completely randomized design in factorial with 3 replications. Each experimental unit consisted of one bag $(40 \times 25 \mathrm{~cm})$ containing $2.2 \mathrm{~kg}$ compost and $660 \mathrm{~g}$ casing soil. Initially, $2.2 \mathrm{~kg}$ compost spawned with white strain (192915 AG, Soc, France) of $A$. bisporus was added into each bag and incubated at $25{ }^{\circ} \mathrm{C}$ for 7 days. Within this period, the strain of $A$. bisporus partially colonized the compost. Afterwards, $3 \mathrm{ml}$ inoculum $\left(1 \times 10^{6}\right.$ conidia $\left./ \mathrm{ml}\right)$ of each isolate of T. aggressivum f. aggressivum was injected into the midsection of each bag using a syringe. Three days later, in the treatments, $5 \mathrm{ml}$ suspension $\left(10^{8} \mathrm{cfu} / \mathrm{ml}\right)$ of each bacterial isolate was injected into the compost nearly $5 \mathrm{~cm}$ above from the section in which $T$. aggressivum $\mathrm{f}$. aggressivum inoculum was given. Commercial biological 
preparations were applied as the same way for each bag in the treatment plots (A. bisporus $+T$. aggressivum f. aggressivum + Bacterial isolate/Commercial biological preparation).

In the experiment, two separate controls were arranged for each treatment plot. In negative controls, neither $T$. aggressivum f. aggressivum nor the bacterial isolates/commercial biological preparates were applied to compost, but only the strain of A. bisporus grew in the compost. In positive controls, no bacterial isolates/ commercial biological preparations were applied but just green mold inoculum ( $T$. aggressivum f. aggressivum) was given into the compost containing the strain of $A$. bisporus. All bags were kept at $25{ }^{\circ} \mathrm{C}$ for 10 days with 85 to $90 \%$ relative humidity. Afterwards, casing soil $(660 \mathrm{~g})$ was added to the top of each bag. Ten days later, temperature in the room was reduced $1{ }^{\circ} \mathrm{C}$ per day until reaching to $17{ }^{\circ} \mathrm{C}$. Afterwards, ventilation providing oxygen from outside into the room was initiated and thus carbon dioxide level in the room was reduced. Casing soil was daily watered by spraying sterile water to keep its dampness. Ensuing emergence of fruiting bodies (sporophores) of the strain of $A$. bisporus, mushrooms in marketing size were picked and weighed per bag. Yield values of each treatment, negative and positive control plots, were calculated separately. Efficacy of each treatment was assessed by comparing both control plots.

Casing soil experiment was conducted according to a completely randomized factorial design with 3 replications. Each experimental unit was composed of one bag (2.2 kg compost $+660 \mathrm{~g}$ casing soil). Initially, neither $T$. aggressivum $\mathrm{f}$. aggressivum nor the bacterial isolates were applied to the compost in this experiment. The compost containing spawn of the strain (192915 AG, Soc, France) of $A$. bisporus was kept at $25{ }^{\circ} \mathrm{C}$ for 19 days. Within this period, mycelium of the strain of $A$. bisporus colonized the compost in each bag. Later, casing soil $(660 \mathrm{~g})$ per bag was laid on the top of the compost in each bag. Addition of casing soil formed nearly 4- to $5-\mathrm{cm}$ thick layer on the top of the compost. In this stage, in the treatments, $3 \mathrm{ml}$ inoculum $\left(1 \times 10^{6}\right.$ conidia/ $\mathrm{ml}$ ) of each isolate of $T$. aggressivum $\mathrm{f}$. aggressivum was injected into central part of the casing soil. Following inoculation of $T$. aggressivum f. aggressivum, 1 day later, $5 \mathrm{ml}$ bacterial suspension $\left(10^{8} \mathrm{cfu} / \mathrm{ml}\right)$ of each bacterial isolate was injected into the same central part of the casing soil in the treatments. The commercial biological preparations were aplied as the same way for each bag in the treatment plots. In the experiment, 2 separate controls were arranged as aforementioned in compost experiment. In addition, as aforementioned, the same mushroom-growing conditions were maintained, and the same experimental evaluations were done.

\section{Statistical analysis}

Analysis of variance (ANOVA) was done using SAS 9.1 software program (SAS Institute Inc., Cary, NC, USA). In vitro and in vivo experiments were conducted using 4 and 3 replicates for each treatment in each experiment, respectively. In vitro experimental data were analyzed using one- and two-way ANOVA, while in vivo experimental data were analyzed using three-way ANOVA. Mean values of each experiment in vitro and in vivo were grouped according to Tukey's multiple range test with significance level of $1 \%$. Dunnett test $(P<0.01)$ was also used to compare treatment plots with positive and negative control plots in in vivo experiments.

\section{Results}

\section{Assessment of in vitro experiments}

As a result of morphological and molecular identification, native bacterial isolates (MSG-5, MSG-11, MSG15, SGM-1, and SGM-2) were identified as Bacillus subtilis, Stenotrophomonas maltophilia, Pseudomonas rhodesiae, and Bacillus amyloliquefaciens, respectively.

In addition, certain features of commercial biological preparations (Tic-1, Tic-2, and Tic-3) used in vivo experiments are given in Table 1.

In dual culture tests, compared with controls, presence of each bacterial isolate in the same artificial medium (CEM) caused significant $(P<0.01)$ inhibitory effect on the mycelial growth of both $T$. aggressivum $\mathrm{f}$. aggressivum and $A$. bisporus in the treatments.

In this respect, the highest growth inhibition (46.60\%) was found in the interactions between bacterial isolate MSG-15 (Pseudomonas rhodesiae) and T. aggressivum $\mathrm{f}$. aggressivum isolate Çom1. However, the lowest growth inhibition (38.61\%) was detected in the interactions between bacterial isolate SGM-2 (Bacillus amyloliquefaciens) and T. aggressivum f. aggressivum isolate K39.

Compared with controls, bacterial isolate MSG-11 (Stenotrophomonas maltophilia) caused up to 56.94\% growth inhibition on the strain of $A$. bisporus in dual culture tests, whereas bacterial isolate SGM-1 (B. amyloliquefaciens) showed the lowest growth inhibition (31.23\%) on the strain of A. bisporus.

Examples of interactions between the 5 bacterial isolates and 2 isolates of $T$. aggressivum f. aggressivum on CEM are shown in Figs. 1 and 2. In addition, examples of interactions between 5 bacterial isolates and the strain of A. bisporus on CEM are given in Fig. 3 in dual culture tests.

\section{Assessment of in vivo experiments Assessment of compost experiment}

Application of the bacterial isolates/commercial biological preparations in compost inoculated with $T$. aggressivum $\mathrm{f}$. aggressivum led to significant $(P<0.01)$ 
Table 1 Commercial biological preparations used in compost and casing soil experiments

\begin{tabular}{lllll}
\hline Designated names in the experiments & Commercial names & Formulation & Biological preparations & Concentrations \\
\hline Tic-1 & Serenade (SC)-Bayer & Liquid & Bacillus subtilis QST 713 & $1 \times 10^{9} \mathrm{cfu} / \mathrm{ml}$ \\
Tic-2 & Cedriks (SL)-Agrobest & Liquid & Pseudomonas fluorescens Pf1 & $1 \times 10^{8} \mathrm{cfu} / \mathrm{ml}$ \\
Tic-3 & Ovnier (SL)-Agrobest & Liquid & Ampelomyces quisqualis Ag1 & $2 \times 10^{6} \mathrm{cfu} / \mathrm{ml}$ \\
\hline
\end{tabular}

effects on the yield of $A$. bisporus. In addition, fungus, treatment, and bacterium $\times$ treatment interactions were significant $(P<0.01)$ in the compost experiment.

In comparison of mean yields of each experimental unit (the plot) in the compost experiment, yield values of the treated plots were higher than the positive controls. However, they were lower than the negative controls. Mean yields of the negative control plots ranged from 547 to $449.66 \mathrm{~g}$, while they ranged from 506 to $378.33 \mathrm{~g}$ in the treated plots. Mean yields of the positive control plots varied from 393.66 to $313.33 \mathrm{~g}$.

Compared with positive control plots, native bacterial isolates (MSG-5, MSG-11, MSG-15, SGM-1, and SGM2) exhibited higher yield increases than commercial biological preparations (Tic-1, Tic-2, and Tic-3) in the treated plots. Yield increases induced by the bacterial isolates ranged from 40.56 to $20.74 \%$ in the treated plots, while they ranged from 30.64 to $18.53 \%$ in the treated plots of the commercial biological preparations. Compared with negative control plots, mean yield decreases in the treated plots of the native bacterial isolates varied from 0.68 to $9.69 \%$, whereas they ranged from 6.52 to $13.78 \%$ in the treated plots of the commercial biological preparations (Fig. 4).

In the overall assessment of the compost experiment, differences in mean yields of the treatment, negative and positive control plots were significant $(P<0.01)$. The highest mean yield, $477 \mathrm{~g}$, was detected in negative control plots, while the lowest mean yield, $348.43 \mathrm{~g}$, was established in positive control plots. Mean yield of the treated plots was $453.79 \mathrm{~g}$. Compared with positive controls, application of the bacterial isolates/commercial biological preparations into compost caused on average $30.23 \%$ increase in yield of the treatment plots. However,

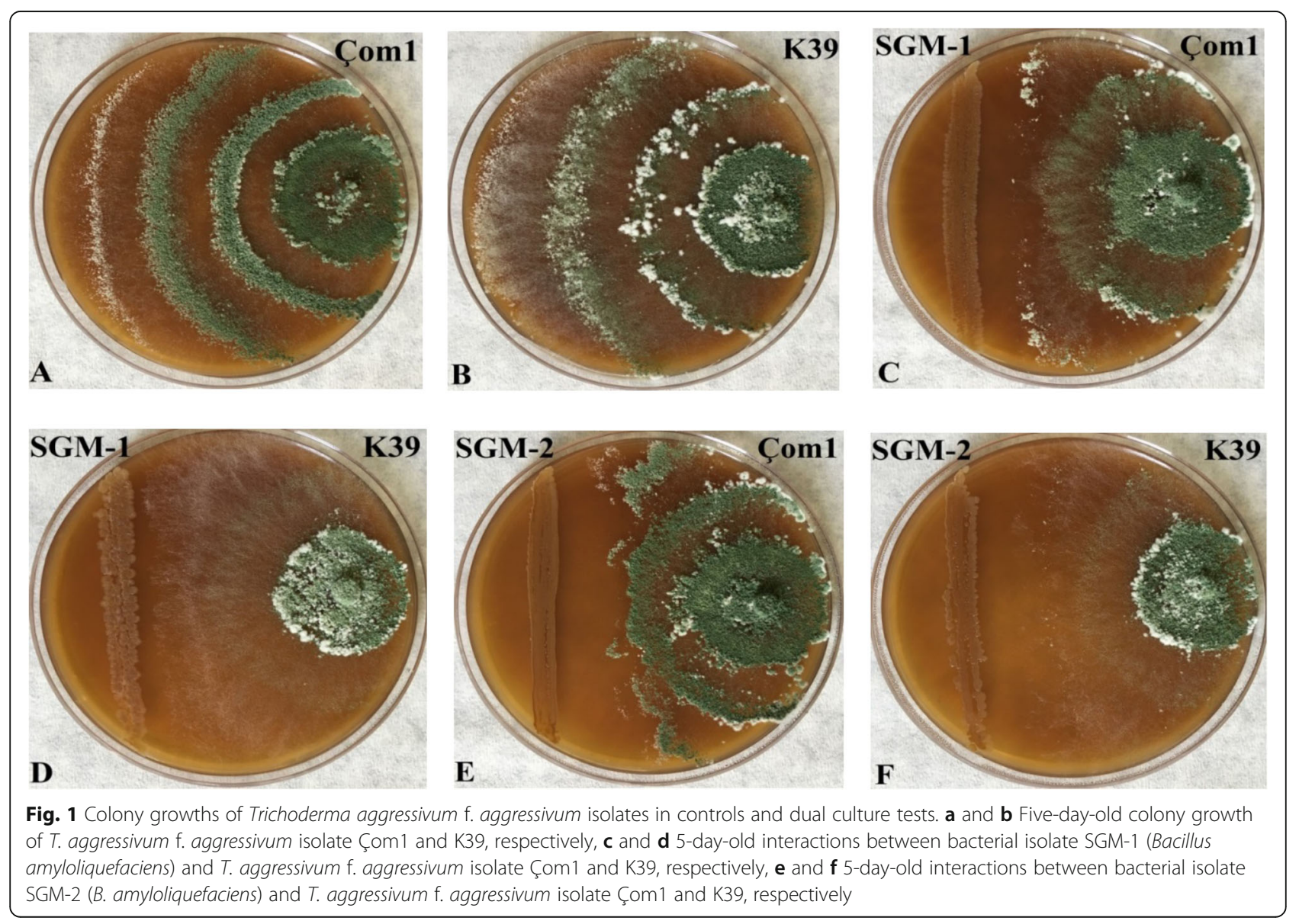



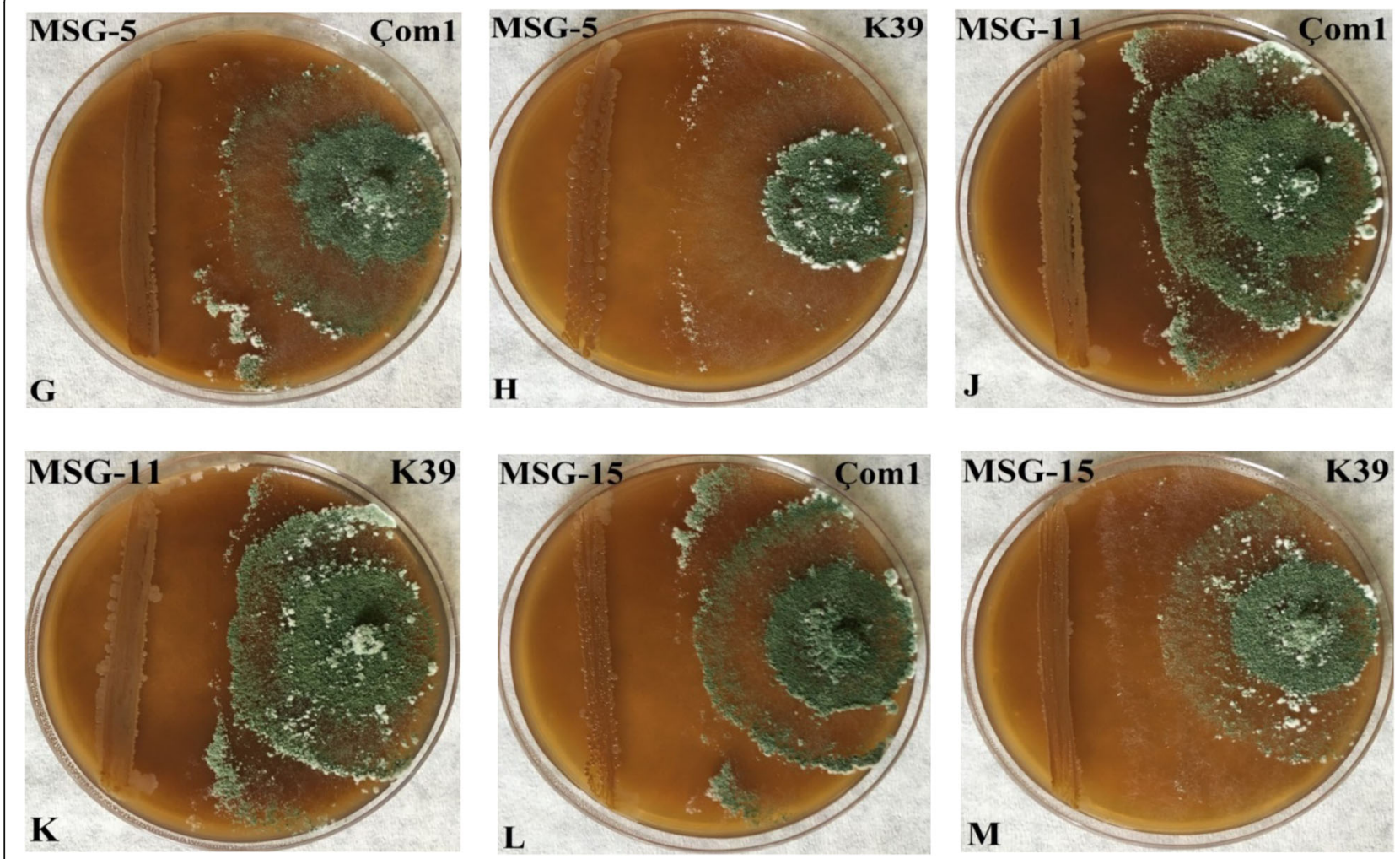

Fig. 2 Dual culture tests. $\mathbf{g}$ and $\mathbf{h}$ Five-day-old interactions between bacterial isolate MSG-5 (Bacillus subtilis) and Trichoderma aggressivum f. aggressivum isolate Çom1 and K39, respectively, $\mathbf{j}$ and $\mathbf{k}$ 5-day-old interactions between bacterial isolate MSG-11 (Stenotrophomonas maltophilia) and T. aggressivum f. aggressivum isolate Çom 1 and K39, respectively, $\mathbf{I}$ and $\mathbf{m}$ 5-day-old interactions between bacterial isolate MSG-15 (Pseudomonas rhodesiae) and T. aggressivum f. aggressivum isolate Çom1 and K39, respectively

compared with negative control plots, their application induced on average $4.86 \%$ decrease in the yield of the treated plots (Fig. 5).

\section{Assessment of casing soil experiment}

Application of the bacterial isolates/commercial biological preparates in casing soil inoculated with $T$. aggressivum $\mathrm{f}$. aggressivum caused significant $(P<0.01)$ effects on the yield of $A$. bisporus. Bacterium, fungus, treatment, bacterium $\times$ fungus, and bacterium $\times$ treatment interactions were also significant $(P<0.01)$ statistically.

In the comparison of yields of each experimental unit (the plot) in the casing soil experiment, mean yields of the treated plots were higher than the positive controls, but they were lower than the negative ones. In this respect, mean yields of negative control plots varied from 474.33 to $416.66 \mathrm{~g}$, while they varied from 414.66 to $325.33 \mathrm{~g}$ in the treated plots. Mean yields of positive control plots ranged from 321.33 to $260 \mathrm{~g}$.

Compared with positive control plots, the native bacterial isolates/commercial biological preparations led to significant $(P<0.01)$ yield increases in the treated plots. The highest yield increase $(36.15 \%)$ was found in the treated plots of Tic-3 (Ampelomyces quisqualis) $\times$ Çom1, whereas the lowest yield increase (15.14\%) was detected in the treated plots of MSG-5 (Bacillus subtilis) $\times$ K39. On the other hand, compared with negative controls, decreases in mean yields of the treated plots ranged from 6.6 to $22.83 \%$ in the casing soil experiment (Fig. 6).

In the overall assessment of the casing soil experiment, the highest mean yield, $440.35 \mathrm{~g}$, was found in negative control plots, while the lowest one, $302.70 \mathrm{~g}$, was detected in positive control plots. Mean yield of the treated plots was $364 \mathrm{~g}$. Differences in mean yields of the treatment, negative and positive control plots were significant $(P<0.01)$. Compared with positive controls, application of the bacterial isolates/commercial biological preparations caused on average $20.25 \%$ increase in yield of the treatment plots but compared with negative controls, their applications induced on the average of $17.33 \%$ decrease in yield of the treated plots (Fig. 7).

\section{Discussion}

Compost is one of the two components for mycelial growth of A. bisporus in button mushroom cultivation. In the present study, the treatments caused significant $(P<0.01)$ yield increases in the compost experiment, indicating efficacy of the treatments (bacterial isolates/ 

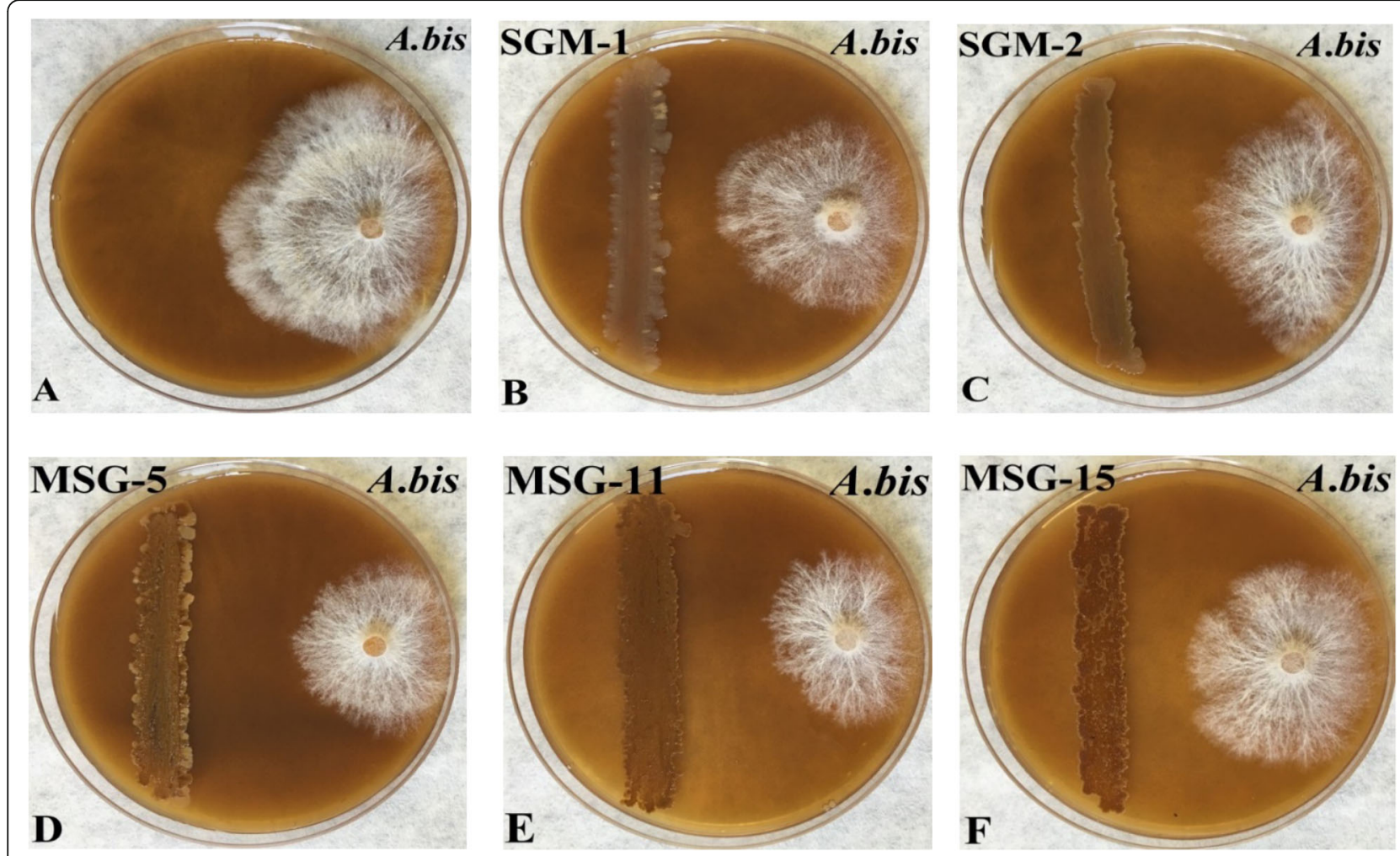

Fig. 3 Colony growth of Agaricus bisporus strain (192915 AG, Soc, France) in control and dual culture interactions between bacterial isolates and the $A$. bisporus strain. a Fourteen-day-old colony growth of the A. bisporus strain in control, $\mathbf{b}-\mathbf{f}$ 14-day-old interactions between bacterial isolates SGM-1 (Bacillus amyloliquefaciens), SGM-2 (B. amyloliquefaciens), MSG-5 (B. subtilis), MSG-11 (Stenotrophomonas maltophilia), MSG-15 (Pseudomonas rhodesiae), and the $A$. bisporus strain, respectively

commercial preparations) on T. aggressivum f. aggressivum in compost. However, it seemed difficult to give a precise explanation regarding mode of action of these treatments because the compost was rich in microbiota including various bacteria, fungi, and yeasts (Siyoum et al. 2016). In such environment, mycelia of the strain of $A$. bisporus colonized compost for nearly 20 days before casing soil addition. Vos et al. (2017) stated that during the compost colonization period, Gram-positive bacteria in compost were less affected by $A$. bisporus than Gram-negative bacteria, indicating interaction of $A$. bisporus with bacteria in compost. This finding may also

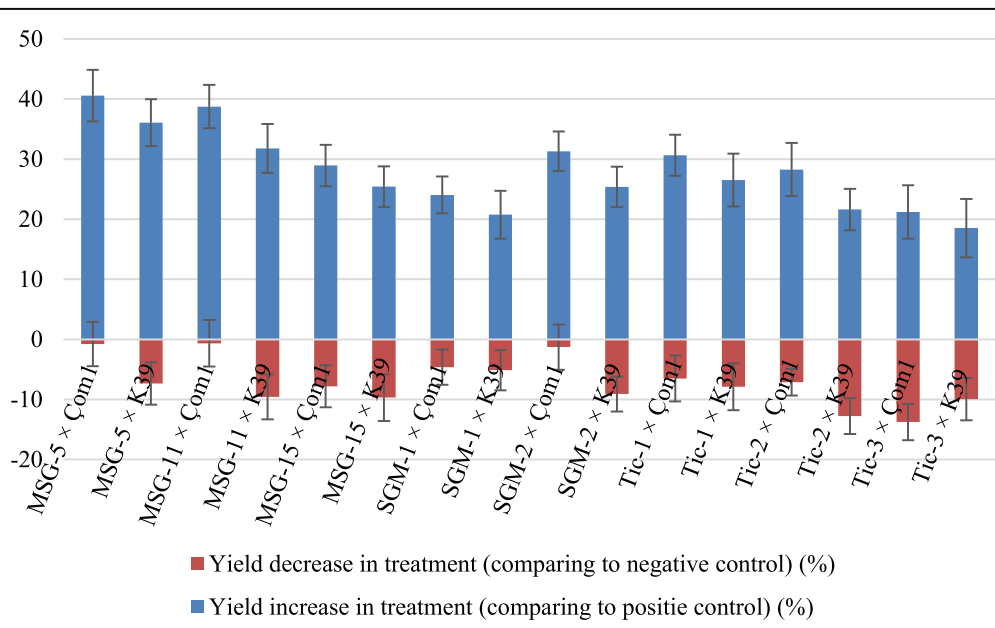

Fig. 4 Comparison of mean yields of the treated plots with positive and negative controls in compost experiment 


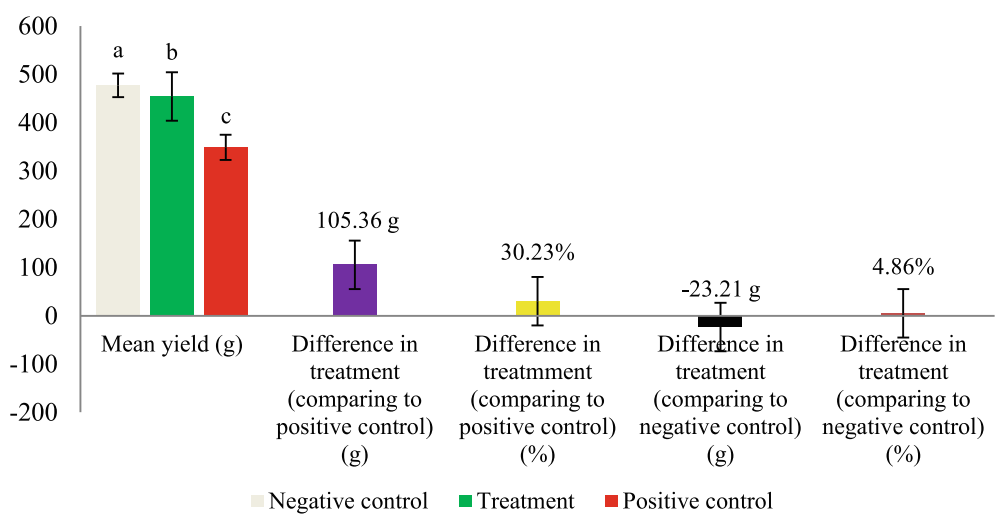

Fig. 5 Overall comparison of mean yields of all the treated plots with positive and negative controls in the compost experiment. Levels not connected by same letter are significantly $(P<0.01)$ different according to Tukey's test. Compared with positive and negative controls, mean yield differences (105.36 and $-23.21 \mathrm{~g}$ ) of the treatments were significant at $P<0.01$ (Dunnett test)

imply that presence of Gram-positive bacteria in compost might have a positive influence on mycelial growth of $A$. bisporus. In this regard, in this study, Grampositive bacterial isolate MSG-5 (B. subtilis) caused the highest yield increase $(40.56 \%)$ in the treated plots by suppressing colonization of $T$. aggressivum f. aggressivum in compost. Likewise, Stanojević et al. (2016) reported that Gram-positive bacterium B. amyloliquefaciens was effective against $T$. aggressivum f. europaeum. However, in the present study, Gram-negative bacterial isolates MSG-11 (S. maltophilia) and MSG-15 (Pseudomonas rhodesiae) also caused yield increases up to 38.73 and $28.93 \%$, respectively, in the treated plots in compost experiment. Similarly, Shah and Nasreen (2011) stated that Gram-negative bacterium (P. fluorescens) caused 23.1\% yield increase by suppressing Trichoderma species in oyster mushroom (Pleurotus ostreatus) cultivation. Considering all of these, it may be inferred that mushroom yield may not be directly related to dominance of either Gram-positive or Gram-negative bacteria in compost.
In the compost experiment, mean yield of the treated plots was $30.23 \%$ higher than the positive control plots, indicating that artificial addition of the bacterial isolates/ commercial biological preparations may have constituted positive effect on yield of $A$. bisporus due to suppresssion of T. aggressivum f. aggressivum in compost. Pandin et al. (2016) reported that B. subtilis QST713 provided a protective effect against $T$. aggressivum f. europaeum in compost and caused a significant yield increase in button mushroom. However, in this study, mean yield of the treatments was $4.86 \%$, lower than the negative control plots, indicating that the application of the bacterial isolates/commercial biological preparations may have induced a negative effect on the yield of $A$. bisporus as well. Likewise, the bacterial isolates displayed inhibitory impact on mycelial growth of $A$. bisporus in vitro, which corroborated the in vivo results. In this context, Kosanović et al. (2013) reported that B. subtilis reduced mushroom yield in treated plots compared with negative controls. Liu et al. (2015) emphasized the negative effect

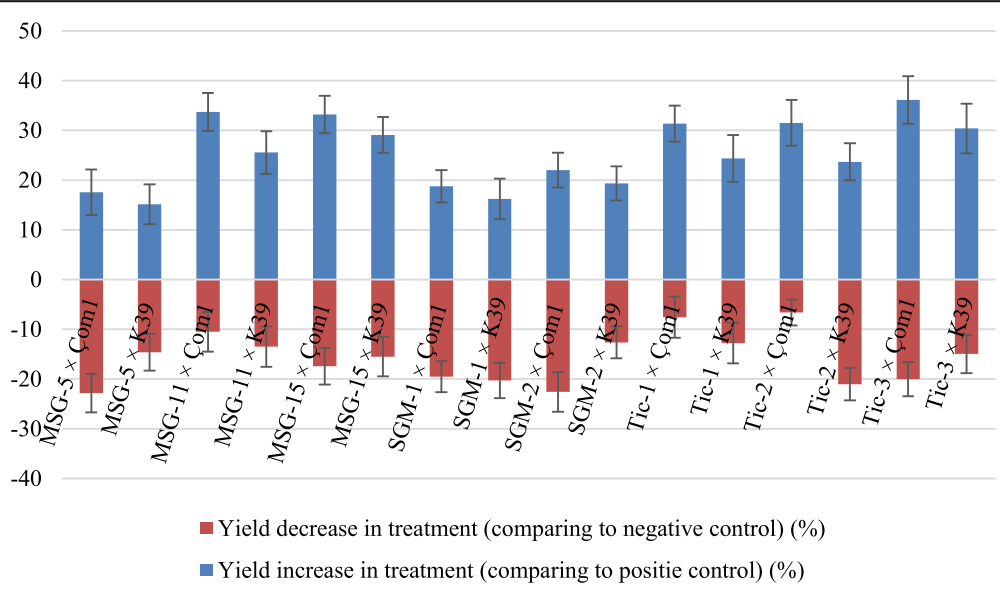

Fig. 6 Comparison of mean yields of the treated plots with positive and negative controls in casing soil experiment 


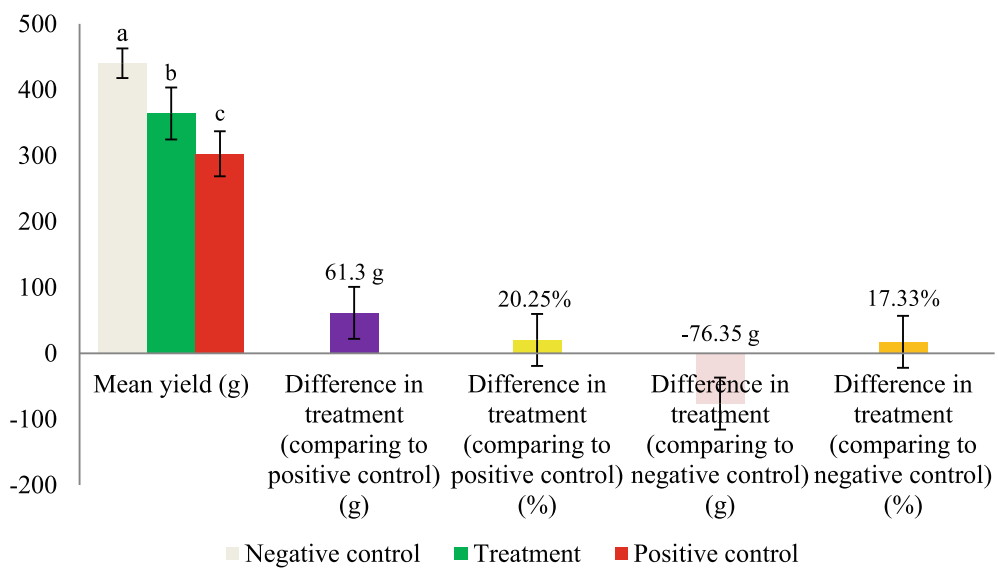

Fig. 7 Overall comparison of mean yields of all the treated plots with positive and negative controls in the casing soil experiment. Levels not connected by same letter are significantly $(P<0.01)$ different according to Tukey's tests. Compared with positive and negative controls, mean yield differences $(61.3$ and $-76.35 \mathrm{~g}$ ) of the treatments were significant at $P<0.01$ (Dunnett test)

of B. subtilis B154 on Neurospora sitophila due to fengycin production (antifungal substance). In addition, in a study, of 20 Bacillus species, some of them displayed antagonistic effects on Trichoderma harzianum, T. koningii, and T. viridescens, while most of them also inhibited mycelial growth of mushroom species (Flammulina velutipes, Lentinus edodes, and Pleurotus ostreatus) in vitro (Kim et al. 2008). All of these indicate that bacteria displaying antagonistic effect on Trichoderma species might also show similar effects on the other fungi like mushroom species including button mushroom $(A$. bisporus). Similarly, significant $(P<0.01)$ inhibitory effects of the bacterial isolates on mycelial growth of both T. aggressivum $\mathrm{f}$. aggressivum and A. bisporus in vitro were found. However, it was difficult to give an exact explanation due to the possibility of occurrence of multiple biotic interactions in compost. Apart from the bacterial isolates/commercial biological preparations added, commercial compost had its own microbiota containing various bacteria and fungi (Pandin et al. 2019). Moreover, various thermophilic actinobacteria (e.g., Saccharomonospora viridis, Streptomyces thermovulgaris, and Thermoactinomyces vulgaris) might be found in compost (Šantrić et al. 2018). Therefore, alterations in microbiota in compost could determine yield stability of $A$. bisporus (Kertesz and Thai 2018).

Casing soil is the other main component of button mushroom cultivation. In casing soil, a vast number of fungi and bacteria involve in complex interactions varying from mutualism to antagonism, which plays a significant role in mushroom yield (Deveau et al. 2018; Kumar et al. 2018 and Carrasco and Preston 2020). In the present study, compared with positive controls, artificial application of the bacterial isolates/commercial biological preparations in casing soil caused significant $(P<$ $0.01)$ yield increases. This implied that the bacterial isolates/commercial biological preparations may suppress T. aggressivum f. aggressivum in casing soil. However, Frey-Klett et al. (2011) reported that mushroom yield might vary depending on bacterial isolate present in the same medium in casing soil. Potočnik et al. (2019) reported that commercial biological preparation $B$. subtilis Ch-13 was more effective than B. velezensis QST713 against $T$. aggressivum f. europaeum in casing soil aplications. In this study, commercial biological preparations (A. quisqualis Ag1 and B. subtilis QST 713), bacterial isolates (S. maltophilia and P. rhodesiae) caused the highest yield increases in the treated plots. Zarenejad et al. (2012) emphasized that artificial addition of $P$. putida in casing soil increased mushroom yield, but some strains of $P$. putida had a negative impact on the development of $A$. bisporus and mushroom yield. From all of these findings, it may be inferred that mushroom yield may vary depending on isolate/strain of bacteria or fungi in casing soil. In this respect, Carrasco et al. (2019) reported that when inoculum levels of some microorganisms are low in casing soil, their growth can be suppressed by natural microbiota, while these microbiata in the casing soil can not suppress high inoculum levels of microorganisms like fungi. This finding is in aggrement with our results of the casing soil experiment. All the treatments caused on average a $20.25 \%$ increase in yield in the treated plots, while compared with negative controls, they caused a $17.33 \%$ decrease in yield. This could be explained as follows: in the presence of a certain amount of T. aggressivum f. aggressivum in casing soil, either the bacterial isolates/commercial biological preparations may not have properly displayed their antifungal potential or the artificially applied microorganisms and natural microbiota in casing soil may not have properly suppressed T. aggressivum f. aggressivum. Another reason could be that the bacterial isolates/commercial 
biological preparations may have negatively affected mycelial growth of $A$. bisporus in casing soil and consequently the yield of $A$. bisporus because in the in vitro experiment, the bacterial isolates showed inhibitory influence on mycelial growth of A. bisporus. Cai et al. (2009) stated that ensuing the addition of casing soil, increasing the amount of Gram-negative bacteria had a significant influence on the sporophore formation of $A$. bisporus. Kim et al. (2008) reported that Bacillus species might show antagonistic activity on green mold, while they might also show the same effect on mycelial growth of mushroom species in vitro. In an in vivo study, Potočnik et al. (2019) reported that Bacillus velezensis QST713 could adversely affect mushroom yield at high application concentrations. Mohammad and Sabaa (2015) reported that in addition to Bacillus species, Pseudomonas bacteria (e.g., P. putida, P. fluorescens, and $P$. aeruginosa) present in casing soil had different effects on A. bisporus. For example, P. putida had a positive effect on mycelial development and mushroom yield of $A$. bisporus, whereas $P$. aeruginosa had a negative effect on $A$. bisporus by reducing yield. From all of these findings, it could be inferred that type and amount of microbiota in casing soil might affect mushroom yield.

Due to the occurrence of multiple interactions between bacteria and fungi, either in compost or casing soil during button mushroom cultivation, addition of biological microorganisms to any of those substrates could positively/negatively affect emerging mushrooms by enhancing/reducing yield (Carrasco and Preston 2020). In the present study, comparing the compost and casing soil experiments, artificial addition of the bacterial isolates/commercial biological preparations to compost caused higher yield increase and created less adverse affects on mycelial growth and yield of $A$. bisporus than those of the casing soil. Similarly, Šantrić et al. (2018) reported that Streptomyces flavovirens A06 was more effective against green mold in compost than casing soil. In this context, functional and biological differences in compost and casing soil may be associated with these findings because A. bisporus initially colonized compost and then casing soil. As a result of aggregation of mycelium of $A$. bisporus, primordia and sporophores of $A$. bisporus emerged on casing soil. In fact, this is a delicate process due to gaining ultimate target (mushrooms) in button mushroom cultivation. Therefore, a little alteration in microbiota in casing soil might affect this delicate process. In previous studies, the importance of casing soil in sporophore formation of A. bisporus was reported (Pardo-Giménez et al. 2017; Szukács and Geösel 2018). Considering all of these, it may be inferred that a little alteration in microbiota in casing soil could significantly affect mushroom yield.

\section{Conclusions}

Irrespective of either Gram-positive or Gram-negative, every single bacterial isolate could be of prime importance in the management of the green mold in button mushroom cultivation. This is also far more important for the management of green mold in compost because fungicides or other alternative management practices could not be used against the green mold in compost due to their possible negative impact on the growth of A. bisporus in compost during mushroom cultivation. Based on the findings of the present study, it could be inferred that an artificial application of bacterial isolates/ commercial biological preparations to compost and casing soil might induce significant yield increases by suppressing green mold, but they might also cause a negative influence on $A$. bisporus. Overall results also suggested that biological control of the green mold in compost might be more efficient than the casing soil.

\section{Acknowledgements \\ We would like to thank SMS Ersanlar Company for providing mushroom compost and casing soil used in the study.}

\section{Authors' contributions}

MA performed most of the experimental work and analyzed the data obtained in the study. SMS identified the bacterial isolates and prepared inoculum for the experiments. IK contributed to the in vivo experiments. GS contributed to molecular identification of the bacterial isolates. The authors have read and approved the manuscript.

\section{Funding}

Culture media, mushroom cultivation room, and laboratory equipment were supplied by Batı Akdeniz Agricultural Research Institute within the scope of the project (TAGEM/BSAD/16/7/02/03) funded by General Directorate of Agricultural Research and Policies, Turkey.

\section{Availability of data and materials}

All data analyzed in the present study are available in the manuscript, and the corresponding author has no objection to the availability of data and materials.

\section{Declarations}

Ethics approval and consent to participate

The study was conducted on green mold fungus (Trichoderma aggresssivum f. aggressivum) and the bacterial isolates (Bacillus subtilis, Stenotrophomonas maltophilia, Pseudomonas rhodesiae, Bacillus amyloliquefaciens) isolated from mushroom compost. These microorganisms are common in mushroom compost and in the environment and do not require ethical approval.

\section{Consent for publication}

Not applicable.

\section{Competing interests}

The authors declare that they have no conflicts of interest.

Received: 13 November 2020 Accepted: 10 March 2021

Published online: 23 April 2021

\footnotetext{
References

Aydoğdu M, Kurbetli İ, Kitapçı A, Sülü G (2020) Aggressiveness of green mould on cultivated mushroom (Agaricus bisporus) in Turkey. J Plant Dis Prot 127(5): 695-708. https://doi.org/10.1007/s41348-020-00328-8

Cai W-M, Yao H-Y, Feng W-L, Jin Q-L, Liu Y-Y, Li N-Y, Zheng Z (2009) Microbial community structure of casing soil during mushroom growth. Pedosphere 19(4):446-452. https://doi.org/10.1016/S1002-0160(09)60137-5
} 
Carrasco J, Preston GM (2020) Growing edible mushrooms: a conversation between bacteria and fungi. Env Mic 22(3):858-872. https://doi.org/1 $0.1111 / 1462-2920.14765$

Carrasco J, Tello ML, Md T, Tkacz A, Poole P, Prerez-Clavijo M, Preston G (2019) Casing microbiome dynamics during button mushroom cultivation: implications for dry and wet bubble diseases. Microbiol 165(6):611-624 https://doi.org/10.1099/mic.0.000792

Chun J, Bae KS (2000) Phylogenetic analysis of Bacillus subtilis and related taxa based on partial gyrA gene sequences. Ant V Leeuw 78(2):123-127. https:// doi.org/10.1023/A:1026555830014

Deveau A, Bonito G, Uehling J, Paoletti M, Becker M, Bindschedler S, Hacquard S, Herve V, Labbe J, Lastovetsky OA, Mieszkin S, Millet LJ, Vajna B, Junier P, Bonfante P, Krom BP, Olsson S, JDV E, Wick LY (2018) Bacterial-fungal interactions: ecology, mechanisms and challenges. FEMS Mic Rev 42(3):335352. https://doi.org/10.1093/femsre/fuy008

Đurović-Pejčev R, Potočnik I, Milijašević-Marčić S, Todorović B, Rekanović E, Stepanović M (2014) Antifungal activity of six plant essential oils from Serbia against Trichoderma aggressivum f. europaeum. Pestic Phytomed 29(4):291297. https://doi.org/10.2298/PIF1404291D

Frey-Klett P, Burlinson P, Deveau A, Barret M, Tarkka M, Sarniguet A (2011) Bacterial-fungal interactions: hyphens between agricultural, clinical, environmental, and food microbiologists. Mic Mol Bio Rev 75(4):583-609. https://doi.org/10.1128/MMBR.00020-11

Geösel A, Szabó A, Akan O, Szarvas J (2014) Effect of essential oils on mycopathogens of Agaricus bisporus. In: Proceedings of the 8th International Conference on Mushroom Biology and Mushroom Products (ICMBMP8) 2014, pp 530-535 http://www.wsmbmp.org/2/76.pdf (Accessed 10 Mar 2020)

Hatvani L, Antal Z, Manczinger L, Szekeres A, Druzhinina IS, Kubicek CP, Nagy A, Nagy E, Vágvölgyi C, Kredics L (2007) Green mold diseases of Agaricus and Pleurotus spp. are caused by related but phylogenetically different Trichoderma species. Phytopathology 97(4):532-537. https://doi.org/10.1094/ PHYTO-97-4-0532

Holt JG, Krieg NR, Sneath PHA, Staley JT, Williams ST (1994) Bergey's manual of determinative bacteriology, 9th edn. Lippincott Williams and Wilkins, Baltimore

Kadaikunnan S, Rejiniemon T, Khaled JM, Alharbi NS, Mothana R (2015) In-vitro antibacterial, antifungal, antioxidant and functional properties of Bacillus amyloliquefaciens. Ann Clin Microbiol Antimicrob 14(1):9. https://doi.org/10.11 86/s12941-015-0069-1

Kertesz MA, Thai M (2018) Compost bacteria and fungi that influence growth and development of Agaricus bisporus and other commercial mushrooms. Appl Microbiol Biotechnol 102(4):1639-1650. https://doi.org/10.1007/s00253018-8777-z

Kim VG, Weon HY, Seok SJ, Lee KH (2008) In vitro antagonistic characteristics of bacilli isolates against Trichoderma spp. and three species of mushrooms. Mycobio 36(4):266-269. https://doi.org/10.4489/MYCO.2008.36.4.266

Kosanović D, Potočnik I, Duduk B, Vukojević J, Stajić M, Rekanović E, Milijašević-Marčić S (2013) Trichoderma species on Agaricus bisporus farms in Serbia and their biocontrol. Ann Appl Bio 163(2):218-230. https://doi.org/10.1111/aab.12048

Kumar B, Kumari C, Kumar M (2018) Effect of bio-fertilizers on mycelial growth and physical properties of white button mushroom [Agaricus bisporus (Lange) Imbach]. Int J Curr Microbiol App Sci 7(2):2216-2222. https://doi. org/10.20546/ijcmas.2018.702.267

Lane DJ (1991) 16S/23S rRNA sequencing. In: Stackebrandt E, Goodfellow M (eds) Nucleic acid techniques in bacterial systematics. New York, Wiley, pp 115175

Liu C, Sheng J, Chen L, Zheng Y, Lee DYW, Yang Y, Xu M, Shen L (2015) Biocontrol activity of Bacillus subtilis isolated from Agaricus bisporus mushroom compost against pathogenic fungi. J Agr Food Chem 63(26): 6009-6018. https://doi.org/10.1021/acs.jafc.5b02218

Milijašević-Marčić S, Stepanović M, Todorović B, Duduk B, Stepanović J, Rekanović E, Potočnik I (2017) Biological control of green mould on Agaricus bisporus by a native Bacillus subtilis strain from mushroom compost. Eur J Plant Pathol 148(3):509-519. https://doi.org/10.1007/s10658-016-1107-3

Mohammad A, Sabaa AK (2015) In vitro and in vivo impact of some Pseudomonas spp. on growth and yield of cultivated mushroom (Agaricus bisporus). Egypt J Exp Biol (Bot) 11:163-167

Pandin C, Darsonval M, Mayeur C, Le Coq D, Aymerich S, Briandet R (2019) Biofilm formation and synthesis of antimicrobial compounds by the biocontrol agent Bacillus velezensis QST713 in an Agaricus bisporus compost micromodel. Appl Environ Microbiol 85(12):e00327-e00319. https://doi.org/1 0.1128/AEM.00327-19

Pandin C, Védie R, Rousseau T, Canette A, Deschamps J, Aymerich S, Le Coq D, Briandet R (2016) Bioprotection of the cultivated mushroom Agaricus bisporus by Bacillus subtilis biofilms. Journée doctorale DIM ASTREA, Paris, France. https://journees.inrae.fr/dim-astrea jdd2016/content/downloa d/3414/35013/version/1/file/Caroline_Pandin.pdf (Accessed 5 Mar 2020).

Pardo-Giménez A, González JEP, Zied DC (2017) Casing materials and techniques in Agaricus bisporus cultivation. In: Edible and medicinal mushrooms: Technology and applications, 1st edn, pp 149-174

Potočnik I, Rekanović E, Todorović B, Luković J, Paunović D, Stanojević O, Milijašević-Marčić S (2019) The effects of casing soil treatment with Bacillus subtilis Ch-13 biofungicide on green mould control and mushroom yield. Pestic Phytomed 34(S1):53-60. https://doi.org/10.2298/PIF1901053P

Rainey PB (1989) A new laboratory medium for the cultivation of Agaricus bisporus. New Zealand Nat Sci 16:109-112

Šantrić L, Potočnik I, Radivojević L, Umiljendić JG, Rekanović E, Duduk B, Milijašević-Marčić S (2018) Impact of a native Streptomyces flavovirens from mushroom compost on green mold control and yield of Agaricus bisporus. J Environ Sci Healt P B 53(10):677-684. https://doi.org/10.1080/03601234.201 8.1474559

Savoie J-M, Mata G, Largeteau M (2016) New prospects in pathogen control of button mushroom cultures. Mush Biotech 6:93-110. https://doi.org/10.1016/ B978-0-12-802794-3.00006-0

Shah S, Nasreen S (2011) Evaluation of bioagents against the infection of green mould (Trichoderma spp.) in Pleurotus sajor-caju cultivation. Int J Plant Pathol 2(2):81-88. https://doi.org/10.3923/ijpp.2011.81.88

Siyoum NA, Surridge K, van der Linde EJ, Korsten L (2016) Microbial succession in white button mushroom production systems from compost and casing to a marketable packed product. Ann Microbiol 66(1):151-164. https://doi.org/10.1 007/s13213-015-1091-4

Stanojević O, Milijašević-Marčić S, Potočnik I, Stepanović M, Dimkić I, Stanković S, Berić T (2016) Isolation and identification of Bacillus spp. from compost material, compost and mushroom casing soil active against Trichoderma spp. Arch Biol Sci 68(4):845-852. https://doi.org/10.2298/ABS151104073S

Suslow TV, Schroth MN, Isaka M (1982) Application of a rapid method for gram differentiation of plant pathogenic and saprophytic bacteria without staining. Phytopathology 72(7):917-918. https://doi.org/10.1094/Phyto-72-917

Szukács G, Geösel A (2018) Effects of different casing onto the yield of button mushroom. Rev Agr Rur Dev 7:77-80

Vinale F, Sivasithambaram K, Ghisalberti LE, Marra R, Woo SL, Lortio M (2008) Trichoderma-plant pathogen interactions. Soil Biol Biochem 40(1):1-10. https://doi.org/10.1016/j.soilbio.2007.07.002

Vos AM, Heijboer A, Boschker HTS, Bonnet B, Lugones LG, Wösten HAB (2017) Microbial biomass in compost during colonization of Agaricus bisporus. AMB Expr 7(1):12. https://doi.org/10.1186/s13568-016-0304-y

Zarenejad F, Yakhchali B, Rasooli I (2012) Evaluation of indigenous potent mushroom growth promoting bacteria (MGPB) on Agaricus bisporus production. World J Microbiol Biotechnol 28(1):99-104. https://doi.org/10.1 007/s11274-011-0796-1

\section{Publisher's Note}

Springer Nature remains neutral with regard to jurisdictional claims in published maps and institutional affiliations. 